

\title{
Review
}

\section{A review of the literature: the transition of entry-level paramedic education in Australia from vocational to higher education}

\section{(1961-2017)}

Ingrid Ann Brooks BAppSc(NsgEd), GradDipBusMgt, MEmergHlth, FRCNA is Senior Lecturer ${ }^{1}$; Hugh Grantham MBBS, FRACGP is Professor of Paramedics²; Caroline Spencer BA(Hons), PhD, GradCertEmergHth\&DisasterPreparedne ss is Research Fellow3; Frank Archer OAM, BMedSc(Hons), MBBS, MEd, MPH, FRACGP, FAFPHM, FIMC(RCSEd) is Emeritus Professor ${ }^{3}$

\author{
Affiliations: \\ ${ }^{1}$ Monash Nursing and Midwifery, Monash University, Melbourne, Victoria \\ ${ }^{2}$ Paramedic Unit, School of Medicine, Flinders University, Adelaide, South Australia \\ ${ }^{3}$ Disaster Resilience Initiative, Monash University Accident Research Centre, Melbourne, Victoria
}

\section{Abstract}

\section{Introduction}

Today in Australia, university degree programs provide the education pathway into the paramedic profession reflecting a more than 50-year process of transition from on-the-job first aid training. The formal organisation of paramedic education began in the early 1960s with the establishment of ambulance service training centres. The factors that contributed to this transition are poorly described when compared with that of paramedics in other parts of the world such as the United States and England. The history of Australian paramedic education is important to capture for the benefit of the profession in Australia and to situate it within a global context of modern emergency medical services. This paper examines the peer reviewed and grey literature to chart the transition of Australian paramedic education from vocational to higher education and uncovers signposts of change leading to this transition.

\section{Methods}

Following a systematic search of MEDLINE and CINAHL Plus databases, the university library collection, Google and the websites of Australian ambulance services, Paramedics Australasia (PA) and the Council of Ambulance Authorities (CAA), 31 reports, 12 journal articles and three texts are included in this review.

\section{Results}

Advances in emergency medicine, vocational education training sector reform in the 1970s and 1980s, reviews into ambulance services, health workforce reform and the efforts of PA and CAA contributed to the transition to university-based education, development of university paramedic program accreditation standards and, ultimately, progression towards registration and professionalisation. These signposts of change that chart developments in Australian paramedic education however, proved difficult to uncover in the literature.

\section{Conclusion}

Unexpectedly, this review finds peak Australian ambulance and paramedic professional bodies perceive difficulty in influencing policy direction that impacts the profession. Absence of thorough and detailed accounts of Australian paramedic education keeps hidden a unique and important history. We invite further research to preserve the history of paramedic education in Australia within the public domain, to assist the profession to understand what went before and to inform its future directions.

Keywords:

paramedic; emergency medical technicians; education; Australia

Corresponding Author: Ingrid Ann Brooks, ingrid.brooks@monash.edu 


\section{Introduction}

Today in Australia, university degree programs provide the education pathway into the paramedic profession reflecting a more than 50-year process of transition from on-the-job first aid training. The formal organisation of paramedic education began in the early 1960s with the establishment of ambulance service training centres. Commencing in the late 1970s, the vocational education training (VET) sector accredited education for ambulance officers (as they were then known) and from the late 1990 s education for entry-level paramedics began to shift to the university sector.

The Australian experience is similar to what occurred to prehospital emergency medical services in England and the United States (US). Since the 1960s the educational preparation requirements of English paramedics and US EMT paramedics has come to include university level programs $(1,2)$. Unlike Australia however, university bachelor degree courses are not the predominant education requirement for paramedics in England and the US (1,2).

This paper examines the peer reviewed and grey literature to chart the transition of Australian paramedic education from vocational to higher education and uncover the signposts of change leading to this transition.

\section{Methods}

MEDLINE and CINAHL Plus databases were searched from 1960 to April 2017 using combinations of the terms: ambulance, ambulance officer, paramedic, training, education, graduate, curriculum, history, accreditation, profession, trends, program and Australia. To identify grey literature the same terms were entered into Google search engine with the addition of: federal, national, health, review, inquiry, reform, report and audit. The websites of Paramedics Australasia (PA), the Council of Ambulance Authorities (CAA) and the ambulance services in each Australian state and territory were also searched. The terms 'ambulance' and 'paramedic' were used to search the university library text collection. To obtain any additional publications not revealed from the search strategy, reference lists of identified reports and publications were hand searched.

Inclusion criteria for all searches were publications in English addressing in whole or part Australian entry-level paramedic education, changes to paramedic role affecting education or professional issues arising from changes to paramedic education. Excluded publications dealt with training of non- emergency ambulance staff, volunteers, intensive care paramedics and those addressing paramedic education design, pedagogy or clinical topics. The first author (AB) screened the publications and two authors (FA and $\mathrm{HG}$ ) undertook a second level review for validation of publications for inclusion. The authors were present at many of the significant events in Australian paramedic education and their lived experience informs some of the discussion. Where possible, individual recollections by the authors are supported using multiple sources in the public domain.

\section{Results}

After screening for duplicates, abstracts of 569 articles, synopses of 152 texts and executive summaries of 72 reports were identified. Of these, 12 journal articles, three texts and 31 reports met the inclusion criteria and were reviewed. The results are presented in five sections:

1. Description of Australian paramedic training programs in the VET sector (1961-2002)

2. Transition to university paramedic education programs (1994-2016)

3. Influence of health workforce reform on entry-level paramedic university education (2005-2014)

4. Development of university education standards and external accreditation (1996-2010)

5. Paramedic registration (2003-2017).

\section{Description of Australian paramedic training programs in the VET sector (1961-2002)}

The establishment of ambulance officer training schools in Ambulance Service New South Wales (ASNSW) and Geelong and District Ambulance Service in 1961 mark the start of formal organisation of Australian ambulance service recruit training (3). An interprofessional group of doctors, nurses and ambulance superintendents developed the first Victorian curriculum adapting contemporary hospital-based clinical practice to the pre-hospital setting (3). Nearly a decade later, Queensland established a training school in 1970 and Western Australia (WA) followed in 1974 (Table 1) (4).

All Australian state and territory ambulance authorities ultimately ran their own training schools delivering ambulance officer training as in-house, unaccredited programs. Ambulance medical advisory committees - usually located in the relevant government department in each state and territory, some supported by sessional, ambulance service medical directors; the first being appointed in 1977 (5) - held the responsibility for the development and revision of curriculum. 
Brooks: The transition of entry-level paramedic education in Australia Australasian Journal of Paramedicine: 2018;15(2)

Table 1. Genealogy of Australian paramedic education development (1961-2002) identified from the literature

\begin{tabular}{|l|l|}
\hline Year & \multicolumn{1}{|c|}{ Milestone event } \\
\hline 1961 & First training schools established at ASNSW (3) and Geelong and District Ambulance Service, Victoria (3) \\
\hline 1964 & South Australian and Tasmanian recruits trained in Victoria (3) \\
\hline 1970 & Queensland Ambulance Officers Training Centre established (4) \\
\hline 1974 & Western Australian Ambulance Officers Training Centre established (4) \\
\hline 1976 & Australian Capital Territory ambulance officers joined Victorian training courses (3) \\
\hline 1978 & Certificate of Applied Science (Ambulance Officer) replaced the in-house certificate program in Victoria (3) \\
\hline 1979 & St John SA Ambulance Education Unit VET sector program commenced (13) \\
\hline 1983 & $\begin{array}{l}\text { Certificate of Emergency Care introduced at St John NT; joint training with Northern Territory Community College } \\
\text { (14) }\end{array}$ \\
\hline 1984 & ALS training for Victorian paramedics introduced (3) \\
\hline 1986 & $\begin{array}{l}\text { ASNSW introduced five stages of training to prepare: basic life support, intermediate life support and advanced life } \\
\text { support paramedics (8) }\end{array}$ \\
\hline 1987 & $\begin{array}{l}\text { Associate Diploma in Health Science (Ambulance Officer) replaced certificate program in Victoria (3) } \\
\text { Associate Diploma of Emergency Care replaced certificate program at St John NT (15) }\end{array}$ \\
\hline 1991 & Single entity QAS established and Associate Diploma of Health Science introduced (17) \\
\hline 1995 & $\begin{array}{l}\text { Advanced Diploma in Paramedic Studies at QAS commenced (18) } \\
\text { ALS introduced into NT St John ambulance Associate Diploma (10) }\end{array}$ \\
\hline 2002 & Diploma of Paramedical Science (Ambulance) introduced into NT St John ambulance (16) \\
\hline
\end{tabular}

In the 1960s and 70s the introduction of cardiopulmonary resuscitation (CPR) and development of advanced life support (ALS) and advanced cardiac life support influenced the skills and knowledge requirements of ambulance officers $(3,6-8)$. Western Australia introduced ALS for all ambulance officers from 1978, becoming the first Australian ambulance service to achieve this clinical advance (9). In Victoria, ALS became part of the student curriculum in 1984 (3) and St John in the Northern Territory introduced ALS skills for entry-level students in 1995 (10).

In 1974, the Kangan Inquiry into technical education resulted in the formation of technical and further education (TAFE) as a new national identity with stable national funding that enabled the development of national policies and standards and ultimately the establishment of national awards (11). In 1977, the National Education Committee of the Institute of Ambulance Officers, comprised of medical directors and training managers from each of the state and territory ambulance authorities, developed a national set of learning objectives for the qualified ambulance officer to informed curriculum development and instruction (12). In 1978, the Victorian Ambulance Officers' Training Centre (AOTC) offered the first formal VET sector award, a Certificate of Applied Science (Ambulance Officer) (3). In 1979, the South Australian St John Ambulance Education Unit commenced its VET sector accredited ambulance officer training (13) and in 1983, St John NT introduced formal certificate training in partnership with the Northern Territory Community College (14). By 1987, both St John NT (15) and Victoria (3) had introduced a higher-level qualification - associate diploma level training for ambulance officers. St John NT ultimately offered a diploma level program from 2002 (16). In Queensland, the amalgamation of 96 communitybased ambulance transport brigades services into a single Queensland Ambulance Service (QAS) occurred in 1991, facilitating the development of centralised state-based training (17). In that year, QAS commenced an Associate Diploma of Health Science (17). Four years later an advanced diploma replaced the associate diploma to address the expressed aim of developing a highly skilled paramedic workforce (18).

The authority for accreditation of training programs for ambulance recruits now resided with each state and territory TAFE authority. However, no mainstream TAFE delivered ambulance officer programs directly.

\section{Transition to university paramedic education programs (1994-2016)}

In 1994, a Charles Sturt University (CSU) paramedic degree conversion program for currently employed paramedics, developed in collaboration with ASNSW, heralded a transition to university-based paramedic programs in Australia (19). Other university programs emerged rapidly (Table 2). In 1995, Victoria University (VU) introduced its degree conversion program $(20,21)$ and in 1998, CSU (19) and Flinders University in partnership with South Australian Ambulance Service (SAAS), offered pre-employment paramedic degrees $(13,21)$. 
In 1999, the Victorian Department of Human Services closed the AOTC transferring ambulance officer education to Monash University (22). In partnership with Ambulance Victoria (AV) Monash began offering a post-employment diploma program and conversion bachelor degree in 2000 and a pre-employment bachelor degree in 2004 (21).

Transition to university education occurred later in other states: St John Ambulance WA in association with Edith Cowan University (ECU) introduced a Bachelor of Science (Paramedical Science) in 2004 (23); Queensland University of Technology graduated its first paramedics in 2007 (17); and the University of Sunshine Coast enrolled its first students into a degree program either in 2007 (17) or 2008 (21). A recommendation for continued transition from ambulance service training to university education in the 2007 Queensland Ambulance Service Audit Report provides evidence of perceived benefit of highly trained university-prepared paramedics as providers of sophisticated and advanced patient management (17). In 2011, St John NT entered into a partnership with ECU aiming to offer a Bachelor of Science (Paramedical Science) from 2012 (24).

In addition to undergraduate degrees, double degrees with nursing introduced at CSU in 2002 (19) and Monash University in 2007 and a Graduate Diploma of Paramedicine at the University of Ballarat in 2009 (21), provided alternate paramedic study pathways (Table 2). The CAA website indicates that in November 2017, 17 Australian universities offered paramedic entry-level degrees (Table 3) (25).

Table 3. Summary of accredited paramedic programs in Australian universities, November 2017

\begin{tabular}{|l|}
\hline 20 programs at 17 Australian universities: \\
- 14 paramedic bachelor degrees \\
- three double degrees \\
- two graduate diplomas \\
- one graduate entry program (25)
\end{tabular}

\section{Influence of health workforce reform upon entry-level paramedic university education (2005-2014)}

In 2005, the Productivity Commission Report addressing Australia's health workforce shortage problems considered the potential for a major redesign of the paramedic role to encompass enhanced clinical practice such as a paramedic practitioner (26). After an additional 2 years of postgraduate study a paramedic practitioner, ideally situated in a rural location, would be capable of performing minor surgical procedures, order investigations and operate as a physician assistant (26).

Table 2. Genealogy of transition to university paramedic graduate programs and accreditation development (1994-2016) identified from the literature

\begin{tabular}{|c|l|}
\hline Year & \multicolumn{1}{|c|}{ Milestone event/report } \\
\hline 1994 & $\begin{array}{l}\text { Bachelor of Health Science (Pre-Hospital Care) first paramedic degree conversion in Australia offered at CSU, NSW } \\
(19)\end{array}$ \\
\hline 1995 & Bachelor of Health Science - Paramedic VU degree conversion commenced (20) \\
\hline 1996 & $\begin{array}{l}\text { Adelaide symposium laid the basis for agreement on standards of ambulance officers and for the establishment of a } \\
\text { national body to address education (36) }\end{array}$ \\
\hline 1998 & $\begin{array}{l}\text { Bachelor of Health Sciences (Paramedic) offered in partnership between SAAS and Flinders University (13) } \\
\text { CSU degree opened to new entrants (19) }\end{array}$ \\
\hline 1999 & Bachelor of Health Science - Paramedic VU post-employment degree commenced (20) \\
\hline 1999 & Transfer of Victorian post-employment programs to Monash University (22) \\
\hline 2002 & Bachelor of Nursing/Bachelor of Clinical Practice (Paramedic) CSU double degree commenced (19) \\
\hline 2004 & $\begin{array}{l}\text { Bachelor of Emergency Health (Paramedic) Monash pre-employment degree commenced (21) } \\
\text { Ambulance Education Committee (AEC) of the CAA formed with the responsibility to develop an external } \\
\text { accreditation process (36) } \\
\text { Bachelor of Science (Paramedic Science) commenced at ECU for St John WA (23) }\end{array}$ \\
\hline 2005 & Bachelor of Health Science (Paramedic) QUT in collaboration with QAS commenced (21) \\
\hline 2007 & $\begin{array}{l}\text { Bachelor of Emergency Health (Paramedic/Nursing) Monash commenced (21) } \\
\text { Graduate Diploma of Paramedicine University of Ballarat commenced (21) } \\
\text { Bachelor of Paramedic Science University of the Sunshine Coast commenced (17) }\end{array}$ \\
\hline 2008 & Graduate Diploma of Paramedicine ACU (Ballarat) commenced (21) \\
\hline 2010 & $\begin{array}{l}\text { Guidelines for the Assessment and Accreditation of Entry-level Paramedic Education Programs (37) and the } \\
\text { Paramedic Professional Competency Standards Development Report developed (38) }\end{array}$ \\
\hline 2011 & St John NT partnership with ECU for Bachelor of Science (Paramedical Science) offered from 2012 (24) \\
\hline
\end{tabular}


The submissions of the Australian College of Ambulance Professionals (ACAP - now PA) and CAA to the Productivity Commission supported an enhanced paramedic role $(27,28)$. The CAA had already commissioned a review of possible expanded roles for rural paramedics in ASNSW and QAS (28). This 2006 review proposed a Rural Expanded Scope of Practice model for paramedics that encompassed community engagement, emergency response, scope of practice extension and primary health care (29). The core attributes would be integrated into undergraduate curricula and form the basis for extended skills training at postgraduate level (29).

Furthering the Productivity Commission's agenda, the 2008 National Health and Hospitals Reform Commission (NHHRC) report, A Healthier Future for All Australians (30), proposed the potential for an extended scope of practice role for paramedics, supported in submissions from CAA (31) and PA (32). In 2009, the Australian Health Ministers Advisory Council (AHMAC) National Health Workforce Taskforce consultation document 'Clinical Training: Governance and Organisation', proposed a new national agency (Health Workforce Australia [HWA]) to manage initiatives concerning health workforce clinical education (33). Of note, paramedics were excluded from the listing of health disciplines covered in this document as the report only considered medicine, nursing, dental and the allied health disciplines that did not include paramedics (33). However, it did accept submissions from three unnamed ambulance services and the Department of Community Emergency Health and Paramedic Practice at Monash University (33). In response, ACAP noted that this exclusion highlighted the continued lack of acknowledgement of the critical role paramedics play in the provision of health care and argued that AHMAC should recognise paramedics as allied health professionals and acknowledge their clinical training needs (6). That ACAP submission mentions the rapid growth of university-based paramedic programs and introduction of a national course accreditation process (6).

Ultimately the HWA conducted the Expanded Scope of Practice Program (ESOP) to explore the potential for expanding paramedic roles and related education program development as part of its broader National Health Workforce Innovation and Reform Strategic Framework for Action 2011-2015 (34). The final project report dealt exclusively with the successful pilot of ESOP roles for paramedics (35). The SAAS and ECU developed training pathways, however these were at postgraduate level (35).

\section{In New South Wales, the 2008 Performance Review}

Ambulance Service of NSW report described trials of expanded practice roles for NSW paramedics which aimed to reduce transport of low acuity patients to emergency departments but lacked any information about educational preparation needed for such new role requirements (36). Table 4 summarises the genealogy of all reports.
Table 4. Genealogy of reports related to health and paramedic workforce reform (2005-2014) identified from the literature

\begin{tabular}{|c|c|}
\hline Year & Milestone report \\
\hline 2005 & $\begin{array}{l}\text { Australia's Health Workforce Productivity } \\
\text { Commission report (27) } \\
\text { ACAP response to Productivity Commission (28) } \\
\text { CAA response to Productivity Commission (29) }\end{array}$ \\
\hline 2006 & $\begin{array}{l}\text { O'Meara P, Walker J, Stirling C, et al. 'The rural and } \\
\text { regional ambulance paramedic: moving beyond } \\
\text { emergency response' report to CAA ( } 30)\end{array}$ \\
\hline 2008 & $\begin{array}{l}\text { 'A healthier future for all Australians' NHHRC } \\
\text { interim report (31) }\end{array}$ \\
\hline 2009 & $\begin{array}{l}\text { 'Clinical training: governance and organisation' } \\
\text { National Health Workforce Taskforce report (32) } \\
\text { 'Clinical training: governance and organisation' } \\
\text { ACAP submission (6) }\end{array}$ \\
\hline 2011 & $\begin{array}{l}\text { 'National health workforce innovation and reform: } \\
\text { strategic framework for action 2011-2015' HWA } \\
\text { (33) }\end{array}$ \\
\hline 2014 & $\begin{array}{l}\text { 'ESOP program evaluation: extending the role of } \\
\text { paramedics sub-project. Final report' HWA (34) }\end{array}$ \\
\hline
\end{tabular}

\section{Development of university education standards and external accreditation (1996-2010)}

Before transitioning to higher education, Australian state and territory TAFE authorities required paramedic education programs to meet VET sector competency standards and accreditation requirements. For health professional programs offered at Australian universities, the professions themselves, through external accreditation agencies such as the Australian Medical Council and Australian Nursing and Midwifery Accreditation Council, determine the educational competency requirements and accreditation standards. The start of the transition to higher education for paramedics in 1994 occurred in the absence of such standards and accreditation requirements. In May 1996, a national ambulance symposium held in Adelaide agreed on the need for paramedic education standards and a national education body (Table 2) (37). In 1999, a steering committee recommended that the Convention of Ambulance Authorities (now CAA) form an Ambulance Education Committee (AEC) to address the key educational issues facing the Convention (12). An AEC would provide a national voice on matters affecting paramedic education and enable self-regulation of the ambulance industry to respond proactively and influence progress and change within VET and higher education sectors (12). An AEC would facilitate the development of national standards for endorsing training organisations and address the need for external accreditation of education programs to ensure that graduates of paramedic education providers met the needs and expectations of both the industry and the profession (12). Finally, an AEC would promote national and international portability of paramedic qualifications (12). 
In 2001, the CAA formed an interim AEC that tabled a proposal for external accreditation of university courses. The formation of the AEC in 2004 enabled the committee to take on the responsibility for developing the external accreditation process (37). In 2010, the CAA published Guidelines for the Assessment and Accreditation of Entry-level Paramedic Education Programs and the Paramedic Professional Competency Standards Development Report $(38,39)$. The following year PA, intending to support the design of paramedic curricula and course accreditation, published the Australasian Competency Standards for Paramedics (40).

\section{Paramedic registration (2003-2017)}

Paramedic registration is a recurring topic in recent literature. In 2003, PA supported registration of ambulance practitioners in its submission to the Victorian Government's review of health practitioner regulation (41). The 2008 Performance Review of ASNSW argued that the trend towards university-based paramedic education is one of the factors increasing pressure towards registration of paramedics (36). In 2009, the St John Ambulance Inquiry, Report to the Minister for Health in WA recommended pursuing paramedic registration to ensure high quality paramedic education (42). Stemming from that recommendation, in 2011 AHMAC released a consultation paper Options for Regulation of Unregistered Health Practitioners (43) and in 2012, an Options for Regulation of Paramedics consultation paper (44). PA's submissions to these consultation papers recommended national registration $(45,46)$ but failed to influence the final AHMAC report $(47)$. With further lobbying from PA, on 6 November 2015, the Council of Australian Governments (COAG) Health Council agreed to proceed to enable the inclusion of paramedics into the National Registration and Accreditation Scheme (48). On 19 October 2017, the COAG Health Council announced appointees to the inaugural National Paramedicine Board of Australia (Table 5) (48).

\section{Discussion}

The chronology of paramedic education in Australia from the 1960s while incompletely described in the literature, highlights non-uniform development of VET sector training programs and similar discontinuous transition to university degrees across Australia. The overall trend throughout this period though, reflects an advancement of qualification levels. Ambulance medical directors played a key role through translation of pre-hospital research and advances in emergency medicine to paramedic education programs that continued until transition to university.

Other events that shaped pre-hospital qualifications and training in the late 1970s and 80 s included reform of the training sector. Through the 1980s VET sector reform developed a consistent nomenclature for TAFE awards and national core curricula (11). In 1989, the Dawkins report heralded a transition to a national competency framework that supported portability of qualifications, an Australian Standard Framework and reclassification of previous qualifications against the new standard (11). The Australian National Training Authority established in 1992 led improvements in the VET system based on developing industry specific competency standards and training packages (11). The VET sector training reform during this period provided an opportunity to advance training of ambulance officers (as they were then called) as presented in Table 1.

Table 5. Genealogy of reports related to paramedic registration (2003-2017) identified from the literature

\begin{tabular}{|c|l|}
\hline Year & \multicolumn{1}{|c|}{ Milestone report } \\
\hline 2003 & $\begin{array}{l}\text { 'Submission to the Review of Health } \\
\text { Practitioner Regulation in Victoria' ACAP } \\
\text { Standards Committee (41) }\end{array}$ \\
\hline 2008 & $\begin{array}{l}\text { 'Performance review Ambulance Service of } \\
\text { NSW' (36) }\end{array}$ \\
\hline 2009 & $\begin{array}{l}\text { 'St John (WA) Ambulance inquiry: report to the } \\
\text { Minister for Health' (42) }\end{array}$ \\
\hline 2011 & $\begin{array}{l}\text { 'Options for regulation of unregistered health } \\
\text { practitioners' AHMAC consultation paper (43) }\end{array}$ \\
\hline 2011 & $\begin{array}{l}\text { 'Options for regulation of unregistered health } \\
\text { practitioners. Consultation response' PA (45) }\end{array}$ \\
\hline 2011 & 'The forgotten health profession' PA (50) \\
\hline 2012 & $\begin{array}{l}\text { 'Options for regulation of paramedics' AHMAC } \\
\text { consultation paper (44) }\end{array}$ \\
\hline 2012 & $\begin{array}{l}\text { 'Public risk and paramedic regulation. } \\
\text { Response to the Australian Health Ministers' } \\
\text { Advisory Council consultation paper: options } \\
\text { for regulation of paramedics' PA (46) }\end{array}$ \\
\hline 2013 & $\begin{array}{l}\text { 'Options for regulation of unregistered health } \\
\text { practitioners' AHMAC final report (47) }\end{array}$ \\
\hline 2015 & $\begin{array}{l}\text { COAG Health Council Communique advising } \\
\text { paramedic registration (48) }\end{array}$ \\
\hline 2017 & $\begin{array}{l}\text { Announcement of appointees to the inaugural } \\
\text { National Paramedicine Board of Australia, 19 } \\
\text { October 2017 (48) }\end{array}$ \\
\hline
\end{tabular}

While well-documented reform occurred in the VET sector, events driving the transition of undergraduate paramedic programs from the VET sector to higher education proved difficult to uncover. In South Australia, the SAAS Ambulance Education Unit continued to run its VET program through shared facilities at Flinders University until 2006 (13) and in Victoria, the phasing out of pre-employment programs began in 2006 with all recruitment into AV occurring through the postemployment pathway since 2007 (21). 
Other than the key events described in this paper, the literature, while noting the transition, provides little additional documented evidence about the reasons for the transition of paramedic education to higher education that has occurred nation-wide. The transition to university programs represents a cost shift from state government budgets where ambulance officers undertook training as paid employees, to federally funded education programs with students self-funding their education before employment. Lord contends the cost benefits to ASNSW of university education posed a driver for the development of the degree at CSU (19). While a benefit, it is unlikely to be the major driver as NSW Ambulance still offers a pre-employment VET sector program for trainee paramedics (49).

The literature search uncovered no reviews specifically enquiring into paramedic education that could provide insights to the development of university paramedic programs. We have knowledge of state-based reviews in Victoria conducted between purchasers of ambulance training and providers, however accessing these in the public domain proved impossible.

The advances in paramedic training and education and changes to curriculum inherent in transitioning from VET to university sector are due to changes in paramedic scope of practice, increased responsibility for accurate clinical decision making and treatment such as being able to treat but not transport (21) as well as changes in community expectations of paramedic care (37). While this paper is able to uncover these signposts of change in leading to university degree education of paramedics (Figure 1), the lack of major reports dealing wholly or in part with the story of paramedic education in Australia demonstrates a novel circumstance when compared with the US and England. In the US, federal and emergency medical services (EMS) organisation reports document the events that influenced the development of EMS education (1). In England national policy directions and ambulance service audits and reviews clearly document the drivers that led to the development of university education for paramedics (2). Unlike Australia however, a university bachelor degree level qualification is not the main pathway to paramedic qualification in the US or the England $(1,2)$.

\section{Paramedic professionalisation}

Moving from the VET sector to higher education required the establishment of new standards and processes for accrediting university-based paramedic courses. Now developed, this process identifies the educational standards expected of graduates from entry-level paramedic programs and aims to ensure quality higher education paramedic programs $(38,39)$.

The development of professionally accredited university undergraduate and graduate programs enhances professionalisation and provides the added benefit of spotlighting the role and capabilities of paramedics to other health professions. However, regulation through registration provides the central platform for the development of the paramedic profession (21). Paramedic registration presents as a recurring topic in the inquiries and reviews into ambulance services in NSW (2008) (36) and WA (2009) (42), and is a major focus for $\mathrm{PA}$, which nurtured and readied the profession and lobbied governments for paramedic registration since at least 2003 (41). An idiosyncratic struggle to obtain paramedic registration exists in Australia when compared to the US and England where longstanding processes are in place for registering paramedics $(1,2)$. When introduced, paramedic registration will form the link missing between education standards and accreditation processes.

\section{Paramedic voice}

A surprising finding in the literature exposes the perception of CAA and PA that they are not heard by government at a national level. CAA's response to a $2008 \mathrm{NHHRC}$ report included recommendations for a stronger voice in policy direction affecting paramedics (31). 'The forgotten health profession', a commentary highlighting the omission of paramedics and paramedic services from national health care policy considerations released by PA in 2011, echoed similar concerns (50).

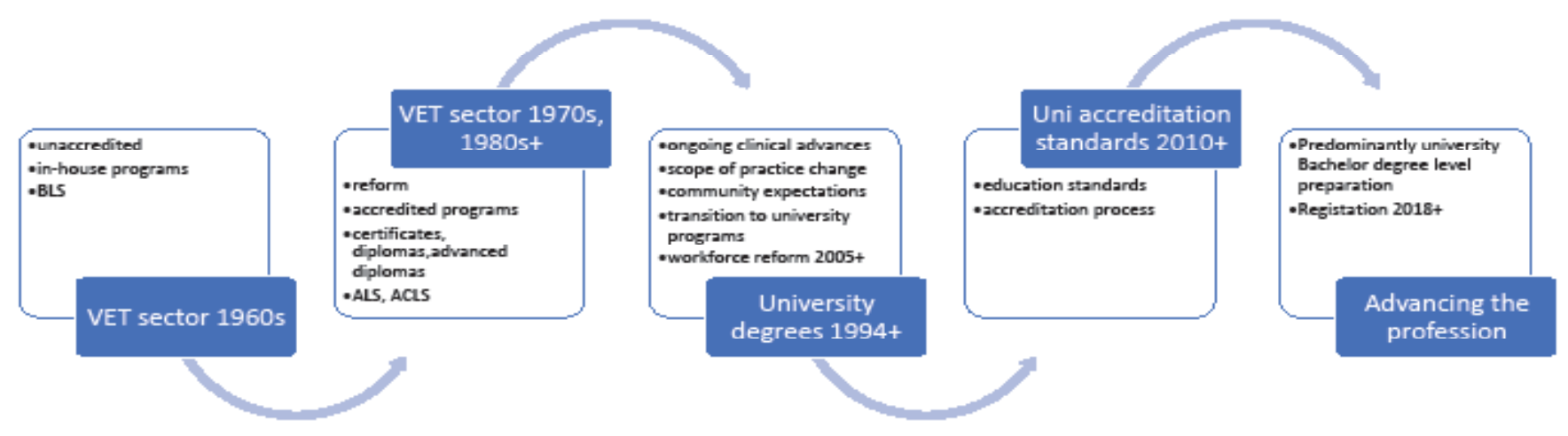

Figure 1. Paramedic education transitions 
This experience contrasts with that of EMS in the US and Ambulance Trusts in England [AUTHOR: UK?] and may be explained by the centralisation of policy setting for pre-hospital emergency service in those countries. In the US, the National Highway Traffic Safety Authority within the Department of Transport holds legislated responsibility for EMS services including training and licensing standards (1) and in England [AUTHOR: UK?] the National Health Service is the central authority for ambulance services emergency pre-hospital care (2).

\section{Conclusion}

Discovering the chronological narrative describing the transition of Australian entry-level paramedic education from VET to higher education reveals a difficult path to uncovering its evolution, development and growth. Inquiries and reviews into ambulance services, federal government initiatives and some peer-reviewed literature chart limited signposts of change that documents a superficial and incomplete history. An unexpected finding from the analysis discloses how Australian peak ambulance and paramedic professional bodies perceive a lack of consultation and an inability to influence policy direction impacting on the profession. Without a thorough account of Australian paramedic education a unique and important history remains hidden. We invite future agents of change within paramedic education to further our research to preserve the history of paramedic education in Australia within the public domain, to assist the profession understand what went before and to inform its future directions.

\section{Limitations}

Potential selection bias exists as many documents remain unobtainable, and some available reports may have been selectively preserved. Lack of resources in the public domain necessitating recollection of author lived experiences contributes to potential memory bias. Where possible this has been countered by checking recollections using multiple sources including secondary hand search of the bibliographies of papers and reports identified from our literature search.

\section{Conflict of interest}

The authors declare they have no competing interests. Each author of this paper has completed the ICMJE conflict of interest statement.

\section{References}

1. Brooks IA, Sayre MR, Spencer C, Archer FL. An historical examination of the development of emergency medical services education in the US through key reports (19662014). Prehosp Disaster Med 2016;31:90-7.

2. Brooks IA, Cooke M, Spencer C, Archer FL. A review of key national reports to describe the development of paramedic education in England (1966-2014). Emerg Med J 2016;33:876-81.

3. Wilde S. From driver to paramedic: a history of the training of ambulance officers in Victoria. Melbourne: Ambulance Officers' Training Centre; 1999, p. 229.

4. Bain C, Jamieson K. Australian ambulance services: a survey of their organisation, funding, staffing, training and equipment together with a brief appreciation of emergency medical services including hospital casualty departments.

Glebe, NSW: Australian Medical Association, Road Safety Committee; 1974, p. 242.

5. Touzel J. Ambulance Service Medical Officer. Circular to Ambulance Superintendents/Secretaries. Melbourne, Vic: Hospital and Charities Commission; 23 December 1976, p. 1.

6. Submission on clinical training: governance and organisation for the National Health Workforce Taskforce. Australian College of Ambulance Professionals; March 2009, p. 22.

7. Lennox G. Review of the ACT Ambulance Service: positioning the service to meet future challenges. Canberra: ACT Government; April 2010, p. 92.

8. Rogan D. For love of life: the story of the first decade of the NSW ambulance paramedics. Sydney NSW: Ambulance Publishing; 1986, p. 111.

9. Oxer H. A shocking affair - defibrillation: a short history. St John History. 2007 May-June;6:3-6.

10. Quirke B. From the principal education officer: the role of the AOTC. Outback Ambulance 1995;8:21,23.

11. Bowman K, McKenna S. The development of Australia's national training system: a dynamic tension between consistency and flexibility. Adelaide, SA: NCVER; 2016, p. 56.

12. Archer F, FitzGerald G, Wilson G, Bielajs I. Convention of Ambulance Authorities proposal for an Interim Australian Ambulance Education Council; 7 October 1999, p. 36.

13. Pointon T. Profile: development of professional paramedic education at Flinders University, Adelaide, South Australia. J Emerg Prim Health Care 2004;2(1/2):4.

14. Burden $C$. From the general manager's desk. Outback Ambulance 1983;1:3.

15. Crawford M. Associate diploma of emergency care. ibid. 1987;1:7.

16. Quirke B. Manager education and training services report. ibid. 2002;12:7,9.

17. Queensland Ambulance Service Audit Report. Queensland Treasury, Department of the Premier and Cabinet; December 2007, p. 244.

18. Woods S, Clark M, Fitzgerald G. Queensland Ambulance Service a case study in organisational reform. Brisbane QLD: Australian Centre for Pre-Hospital Care; 2002, p. 44.

19. Lord $B$. The development of a degree qualification for paramedics at Charles Sturt University. J Emerg Prim Health Care 2003;1(1/2):5.

20. Balon-Rotheram A. The development of professional qualifications for paramedics at Victoria University. J Emerg Prim Health Care 2003;1(3/4):1. 


\section{References (continued)}

21. Joyce CM, Wainer J, Piterman L, Wyatt A, Archer F. Trends in the paramedic workforce: a profession in transition. Aust Health Rev 2009;33:533-40.

22. The Allen Consulting Group. Review of the Ambulance Services Act 1986. Final report. Melbourne, Victoria: Ambulance Services Branch, Corporate Strategy Division, Department of Human Services; April 1999, p. 105.

23. St John Ambulance Western Australia Annual Report 200304. Belmont: St John Commandery in Western Australia; 2004, p. 40.

24. Quirke B. Education and training report. Outback Ambulance 2011;23:4-6.

25. Council of Ambulance Authorities. CAA accredited courses Melbourne, Victoria. Available at: www.caa.net.au/paramediceducation/accredited-courses [Accessed 12 November 2017].

26. Productivity Commission. Australia's Health Workforce. Canberra: Commonwealth of Australia, 2005, p. 435. Available at: www.pc.gov.au/inquiries/completed/healthworkforce/report [Accessed 14 April 2017].

27. Comments on draft proposals Productivity Commission Health Workforce. Australian College of Ambulance Professionals; November 2005, p. 5. Available at: www. pc.gov.au/inquiries/completed/health-workforce/submissions [Accessed 25 June 2017].

28. Response to the Productivity Commission Paper on Australia's Health Workforce. Council of Ambulance Authorities; 2005, p. 3. Available at: www.pc.gov.au/inquiries/ completed/health-workforce/submissions [Accessed 14 April 2017].

29. O'Meara P, Walker J, Stirling C, et al. The rural and regional ambulance paramedic: moving beyond emergency response - report to the Council of Ambulance Authorities Inc. Bathurst NSW: Charles Sturt University, School of Public Health; March 2006, p. 80.

30. A healthier future for all Australians - Interim Report. Canberra, ACT: National Health and Hospitals Reform Commission; December 2008, p. 392. Available at: http://apo. org.au/node/2223 [Accessed 6 March 2017].

31. Submission to the National Health and Hospitals Reform Commission. Council of Ambulance Authorities; May 2008, p. 16.

32. Response to National Health Care Reform Commission Interim Report - A healthier future for all Australians. Australian College of Ambulance Professionals; March 2009, p. 2.

33. Clinical training: Governance and organization. Melbourne, Victoria: National Health Workforce Taskforce; February 2009, p. 30.

34. National health workforce innovation and reform: strategic framework for action 2011-2015. Adelaide, South Australia: Health Workforce Australia; 2011, p. 44.

35. Thompson C, Williams K, Morris D, et al. HWA expanded scopes of practice program evaluation: expanding the role of paramedics sub-project. Final Report. Wollongong, NSW: Centre for Health Service Development, University of Wollongong. July 2014, p. 132. Available at: http://ahsri.uow. edu.au/chsd/projects/esop/index.html [Accessed 3 March 2017].

36. Performance Review Ambulance Service of NSW. Sydney, NSW: Performance Review Unit, Department of Premier and Cabinet; June 2008, p. 128. Available at: www.ambulance. nsw.gov.au/Our-performance/Reviews-and-Inquiries.html [Accessed 2 June 2017].

37. Grantham H. Ambulance education - past, present and future. J Emerg Prim Health Care 2004;2(1/2):2.

38. Guidelines for the Assessment and Accreditation of Entrylevel Paramedic Education Programs. Melbourne, Victoria: Council of Ambulance Authorities and Australasian College of Ambulance Professionals; May 2010, p. 31.

39. Paramedic Professional Competency Standards Development Report. Findon, South Australia: Council of Ambulance Authorities; 2010, p. 38.

40. Australasian Competency Standards for Paramedics. Paramedics Australasia; 2011, p. 11 p. Available at: www. paramedics.org/paramedics/competency-standards/ [Accessed 5 May 2017].

41. Standards Committee ACAP. Submission to the Review of Health Practitioner Regulation in Victoria. J Emerg Prim Health Care 2003;1(3/4):4.

42. St John Ambulance inquiry: Report to the Minister. Department of Health, Government of Western Australia, October 2009, p. 30. Available at: www.health.wa.gov.au/ Reports-and-publications/St-John-Ambulance-Inquiry-Finalreport-to-the-Minister-for-Health-2009 [Accessed 5 May 2017].

43. Options for regulation of unregistered health practitioners. Consultation Paper. Australian Health Ministers' Advisory Council; February 2011, p. 88.

44. Options for regulation of paramedics. Consultation paper. Health Workforce Principal Committee, Australian Health Ministers' Advisory Council; July 2012, p. 127. Available at: www.paramedics.org/content/2012/07/Consultation-PaperParamedic-Registration.pdf [Accessed 2 June 2017].

45. Options for regulation of unregistered health practitioners. Consultation response. Paramedics Australasia; April 2011, p. 18.

46. Public risk and paramedic regulation. Response to the Australian Health Ministers' Advisory Council consultation paper: options for regulation of paramedics. Paramedics Australasia; September 2012, p. 52. Available at: www. paramedics.org/news-corporate/pa-submission-onparamedic-registration/ [Accessed 2 June 2017].

47. Options for regulation of unregistered health practitioners. Final report. Australian Health Ministers' Advisory Council; April 2013, p. 201. Available at: www.health.vic.gov.aul pracreg/options-for-regulation-of-unregistered-healthpractitioners [Accessed 2 June 2017]. 


\section{References (continued)}

48. COAG Health Council. Announcements. Appointment of inaugural Paramedicine Board Communique. Adelaide, SA: COAG Health Council; October 2017. Available at: www. coaghealthcouncil.gov.au/Announcements/Announcements [Accessed 8 November 2017].
49. Ambulance Service of New South Wales. Becoming a paramedic. Health, NSW Government. Available at: www. ambulance.nsw.gov.au/employment/paramedic-positions/ becoming-a-paramedic.html [Accessed 25 June 2017].

50. The forgotten health profession. Paramedics Australasia; September 2011, p. 12. Available at: www.paramedics.org/ the-forgotten-health-profession-3/ [Accessed 25 June 2017]. 